\title{
Primary Drivers of Sustainable Performance: The Case of Corporate Waqf
}

\author{
Aliza Ramli (Corresponding Author) \\ Faculty of Accountancy, Universiti Teknologi MARA, Malaysia \\ Tel:+603-32587397 Email: aliza629@salam.uitm.edu.my \\ Fadzlina Fahmi \\ Faculty of Accountancy, Universiti Teknologi MARA, Malaysia \\ Tel: +603-3258 7456 Email: fadzli686@salam.uitm.edu.my \\ Faizah Darus \\ Accounting Research Institute, Universiti Teknologi MARA, Malaysia \\ Tel: +603-5544 4990 Email: faiza634@salam.uitm.edu.my \\ Nurlida Ismail \\ Taylor's University, Malaysia \\ Tel: +603-32587397 Email: nurlida.ismail@taylors.edu.my
}

\begin{abstract}
s
Despite Waqf institutions being perceived as the social mechanism to facilitate equitable economic growth and progress for the ummah, getting its concept accepted and implemented by business organizations remains a challenge. A significant number of waqf institutions are also faced with recurring issues such as underdeveloped waqf properties, unproductive nature of the assets, inability to generate self-income, loose documenting system and mismanagement. Therefore, this paper aims to shed light on the drivers of the successful practice of corporate waqf of a selected waqf institution in Malaysia. Specifically, this paper examines the critical factors that continuously drive the performance of the corporate waqf institution. The framework for the case study was premised upon the tawhidic concept which stemmed from the Quran and Sunnah. In the case study, data were drawn from interviews with key informants, participant observations and reviews of documents. Data collected from multiple sources of evidence enabled the triangulation of data. The situation has enhanced the validity and reliability of the findings. NVivo software was used to code and analyze
\end{abstract}

the data as well as to search for patterns and emerging themes. The results revealed that the case company successfully engaged in waqf practice as well as, sustain its performance. The essential criteria in managing and administering waqf funds at the case company can be linked to the jihad attitude, healthy mindset, an in-depth knowledge of Islamic and waqf fundamentals and strategic leadership. The findings put forth to advance the literature on corporate waqf besides provide insights for policymakers on the drivers for an effective and efficient management of waqf funds and sustainable corporate waqf performance.

Keywords: Corporate Waqf, Tawhidic, Sustainable Performance, Case study

\section{Introduction}

Waqf has the potential to provide the solution to elevate the welfare of the disadvantaged community. Waqaf, an Islamic trust or endowment enables the act of retaining certain property with intention of using the benefits for philanthropic purposes, and its use is prohibited outside of its specific objective (Ibrahim \& Ibrahim 2013). Although it is not a compulsory 
act, Muslims practice waqaf to obtain Allah's blessing. It is also seen as a mechanism for them to share wealth with the ummah. As mentioned in surah Al-Zariyaat "And in their wealth there is due share for the beggar and the deprived". According to Hodgson (1974, p.24) as cited in Toraman, Tuncsiper \& Yilmaz (2007), waqf can be seen as a "vehicle for financing Islam as a socieety". Thus, waqf can be a tool to develop the economy of a country (Ibrahim \& Ibrahim 2013).

However, a significant number of waqf institutions are faced with recurring issues such as underdeveloped waqf properties, unproductive nature of the assets, inability to generate self-income, loose documenting system and mismanagement. For example, the loose system in documenting waqf donation led to waqf properties being exposed to mismanagement and corruption (Ibrahim \& Ibrahim 2013). This situation occurs when the properties are not managed in accordance with the original purpose of the donor. They added that waqf authorities in some Islamic and non-Islamic countries were blamed for underdeveloped and negligent of waqf properties (Ibrahim \& Ibrahim 2013). The recurring issues faced by waqf institutions suggest that waqf institutions in Malaysia have yet to efficiently contribute to addressing the economic problems of the ummah (Arshad \& Zain 2017). It was reported that generally in 2014, waqf properties were not being managed effectively by the State of Islamic Religious Council (SIRCs) (The Auditor General's Report 2014). According to Arshad and Zain (2017), the Auditor General has recommended SIRCs to improve their management of waqf properties so that the ummah can obtain socio-economic benefits from the properties.

Further, despite waqf institutions being perceived as the social mechanism to facilitate equitable economic growth and progress for the ummah, getting its concept accepted and implemented by business organizations remains a challenge. Additionally, limited studies that examine corporate waqf specifically in the context of the management of waqf institutions are observed (Saad, Kassim \& Hamid 2013; Johari, Mustaffa \& Hameed 2016). Thus it is against this backdrop that this paper aims to find the answer to the following questions:

(i). How is the performance of the selected corporate waqf case institution?

(ii). What key factors enable the effective management of waqf funds within the selected corporate waqf case institution?

The remainder of this paper is organized as follows. Section 2 presents the literature review while section 3 discusses the research methodology adopted in the study. Section 4 presents the results and discussions. Section 5 concludes the paper.

\section{Literature Review}

\section{Fundamentals of Waqf}

Since the Golden Age of Islam, waqf has always been regarded as one of the most influential charitable organizations which serve as a social mechanism to achieve the objective of equitable and just distribution of wealth in an Islamic economic system. Waqf is an act of retaining specific properties for the benefit of others. It is the holding and preventing of an asset or Maal with the aim of using the benefits in meeting its objectives of philanthropy (Kahf 1998). Waqf normally relates to immovable property endowed by the donor. However, it also covers donation of movable property, usufruct and cash (Darus, Shukri, Yusoff, Ramli, Mohamed Zain \& Abu Bakr 2017). They highlighted that the expanded forms of waqf given in the definition of waqf by Monzer Kahf (2003) emphasized that the recurrence of the benefit obtained from the donated property need not necessarily derived from only immovable property. Further to that, Darus et al. (2017) stated that waqf could be utilized as a possible source of funding by Islamic institutions to provide perpetual funds for their social responsibility programs. 
Waqf can be categorized into general waqf or specific waqf (Rahman 2009). The purpose of the general waqf is to enhance the image of the poor, orphans, widows or others and Islam as a whole. In other words, there is no indication of who the beneficiaries are. Meanwhile, for the specific waqf, the donor specified that the funds should be used solely for the needy or for the graveyard. Waqf institutions according to Nadwi (2015), aims to (i) ensure waqf properties provides a vehicle for the perpetual reward for the donor and (ii) contributes to significant socio-economic benefits to the society specifically, the less privileged. In this respect, donors view waqf as more attractive since it enables rewards to be obtained even after the demise of the donors. On the other hand, the benefits derived from other charities do not extend to the afterlife.

Prophet Muhammad (peace be upon him) greatly emphasized on the waqf of orphans. Prophet Muhammad (PBUH) said

\section{"Whoever treats an orphan girl or boy well, I will be with him on the Day of Resurrection like these, and he pointed to his two fingers, the index finger and the middle finger."}

The legitimacy of waqf can be inferred from Surah Al Imran in the Quran that says

\section{"You shall not receive goodliness unless you spend out of that which is dear to You."}

Further evidence can be gleaned from the Quranic verse that says

\section{"When human being dies, his work for God comes to an end except for three: a lasting charity, knowledge that benefits others and a good child who calls on God for his favour."}

Thus, complying with the verse, Abu Talha endowed his exquisite garden for waqf which was approved by the Prophet (PBUH). In essence, waqf mainly provides certain effort of improving the wellbeing of the ummah, and any of its utilization that is beyond its intended purpose are prohibited (Zahrah 2007).

\section{Waqf Institutions in Malaysia}

The revival of waqf institutions continues to present them as the cornerstone for establishing operative economic enhancement for Muslim societies. However, the lack of management, mismanagement, and accountability are some of the issues associated with waqf authorities that gave rise to the engagement of corporate bodies in managing waqf affairs in Malaysia (Ibrahim \& Ibrahim 2013). Corporate waqf, a novelty introduced by Johor Corporation in 2006 refers to the merging of corporate efforts with the purpose of giving back to the society through waqf concept. It is viewed as an innovation that intents to revitalize the once formidable waqf institution besides benefiting from its dynamism that facilitates wealth creation by way of business and corporate efforts to spur economic growth (Saad, Kassim \& Hamid 2013). They highlighted that its primary advantage lies in its longevity, which could address the issue relating to maintaining corporate ownership and continuity to serve the ummah. Corporate waqf can also be viewed as a way to enhance the implementation and administration of waqf property as stipulated in the Corporate Management Code 2012 and Corporate Management Structure 2011 under the supervision of Securities Commission (Ministry of Finance 2011). The realization of corporate waqf concept was through the IQRA foundation formed under the Trustee Act 1952 (Act 258) that established Baitul Awqf Fund (BAF). Through BAF, IQRA foundation is appointed as the Maukuf Alaihi who is given the authority to receive cash and waqf shares from individuals and corporations. Meanwhile, the financial securities institutions are given the power as Mutawali registered under BAF to manage the waqf as agreed in the waqf deed (Ministry of Finance 2011). 


\section{Management of Waqf}

In the context of the present article, sustainable performance relates to the ability of the waqf institution to continue to efficiently manage and distribute waqf properties to the beneficiaries. In other words, the organization can provide the continual contribution to the socioeconomic benefit of the ummah. A review of the literature suggests that limited studies being conducted to examine the efficiency of managing waqf institutions (Saad, Kassim \& Hamid 2013; Johari, Mustaffa \& Hameed 2016). The investigation by Ibrahim et al. (2009) that compared between waqf and charity organizations in the United Kingdom revealed that the management of waqf could improved by ensuring internal financial controls, transparency and reporting, management of funds and, the Code of Good Governance are in place in the institutions. Additionally, Osman (2010) proposed waqf institutions to adopt participative accountability to improve the effectiveness of waqf management. They recommend listening, as well as, conducting a dialogue with beneficiaries. A similar finding was found in the study by Hassan and Shahid (2010). They reported that the application of stakeholders' principle in managing waqf could improve the performance of waqf institutions. As stated in the Holy Quran (2:284),

\section{"To Allah belongs all that is in the heavens and on earth, whether you show what is in your minds or conceal it, Allah will call you to account for it."}

Accountability in the context of Islamic perspective relates to the concept of amanah (trust) as well as, khalifah (vicegerent) (Noordin, Haron \& Kasim 2017). This suggests that an individual's primary accountability is to the creator Allah followed with the secondary accountability to others premised upon the contract established by both parties (Sulaiman, Adnan \& Nor., 2009). In other words, through the concept of accountability in Islam, effective management of waqf institutions hinges on the establishment of the relationship between the provider and the trustee or manager of waqf funds.

\section{Methodology}

This exploratory study adopts the qualitative methodology that focusses on words instead of the quantification of data collection and analysis (Bryman \& Bell 2011). The methodology is viewed as appropriate when the researcher either examines the new field of study or intends to ascertain and theorize prominent issues (Strauss 2008). It is also best suited to address a research problem in which the researcher does not know the variables and need to explore (Creswell 2012). The use of qualitative methodology also enables a prospective researcher to fine-tune the preconceived notions besides extrapolating the thought process, analyzing and estimating the issues from an in-depth viewpoint (Jamshed 2014). This study uses the case study method in which data were drawn from interviews with key informants, participant observations and reviews of the document. Data collected from multiple sources of evidence enabled the triangulation of data. This has enhanced the validity and reliability of the findings. However, the semi-structured interview was the primary source of qualitative data used in the present study. Semi-structured interviews are in-depth interviews in which informants have to answer pre-set open-ended questions (Jamshed 2014) and thus, are used extensively in many qualitative studies in areas such as management accounting and healthcare. Through the utilization of qualitative data, the focus on nuance, setting and interdependence, and increased depth of understanding of the cases and programs examined can be achieved (Ritchie \& Lewis 2003). The interview technique is also useful to understand behavior and behavior change (Aziz \& Ismail 2011). However, Patton (2002) pointed out that it is soft and unscientific, and it will reduce the statistical generalisability. 
Gugui \& Rodriguez-Campos (2007) emphasized that informants selected for interview were premised on them possessing information of value to the study. As such, semi-structured interviews were conducted face to face either individually or by the focus group on the field site with personnel from the case company. Table 1 provides a summary of the interviews conducted for this study. In total, ten face to face semi-structured interviews either by individual or focus-group basis were conducted at the institution's premise.

Table 1: Summary of Semi-structured Interviews

\begin{tabular}{|c|c|c|}
\hline $\begin{array}{l}\text { Types of } \\
\text { Interview }\end{array}$ & $\begin{array}{l}\text { Job Title of } \\
\text { Informants }\end{array}$ & $\begin{array}{l}\text { Interview } \\
\text { duration }\end{array}$ \\
\hline Focus group 1 & $\begin{array}{l}\text { Vice President } \\
\text { General Manager }\end{array}$ & $\begin{array}{l}2 \text { hours } 15 \\
\text { minutes }\end{array}$ \\
\hline Individual & Advisor & $\begin{array}{l}1 \text { hour } 30 \\
\text { minutes }\end{array}$ \\
\hline Individual & Waqf Secretariat & 2 hours \\
\hline Focus group 2 & $\begin{array}{l}\text { Beneficiary } \\
\text { Beneficiary }\end{array}$ & 1 hour \\
\hline Focus group 3 & $\begin{array}{l}\text { Beneficiary } \\
\text { Beneficiary }\end{array}$ & 1 hour \\
\hline $\begin{array}{l}\text { Individual } \\
\text { (follow-up) }\end{array}$ & Vice President & 2 hours $30 \mathrm{mins}$ \\
\hline Individual & Islamic Scholar & 1 hour \\
\hline
\end{tabular}

The semi-structured interviews were based on interview protocol while probing questions were used to pursue issues and to enhance understanding of responses. The interview protocol comprised of the core question and associated questions related to waqf context, factors that improve the institution performance and measures for the waqf institutions as well as the beneficiaries. These procedures have contributed to improved validity and reliability of conducted interviews (Yin 2009). All digitally recorded interviews were transcribed in verbatim (Muslim \& Abdullah 2013). Field notes were also taken to provide significant information about the circumstances of the interviews not captured by the digital recording. Transcripts are then imported into the NVivo 10 software for data analysis. Data were coded and analyzed to search for patterns and emerging themes.
The document review provided information on organization structure, institution's product and services and performance. Several opportunities for direct observations were also made in the process involved in making the product, product showroom and company's premises. The purpose of the examining organizational documents and making the observations was to provide an understanding of waqf practice, which included its application and output as well as the institutional culture. Data collected from multiple sources of evidence enabled the triangulation of data. The situation has enhanced the validity and reliability of the findings (Yin, 2009). NVivo software was used to code and analyze the data as well as to search for patterns and emerging themes.

\section{Results and Discussion}

This section begins with a brief background of the case company followed with the performance of the waqf institution and the key factors that enable effective management of its waqf properties.

\section{The Case Company: Background and Sustainable Performance}

In this study the selected case company, a waqf organization is disguised as ABC Institution. The case company established in 1988, is a Malaysian foundation registered under Companies Act 1965. It aims to spread the message of Islam throughout the world, to strengthen the faith of Muslim and to revive the field of Islamic art. ABC Institution undertakes two types of waqf; waqf Quran or Quranic Endowment program and waqf educational program. Its other activities also involve the task to compile and record traditional cultural motifs of the Malays that are influenced by the Islamic culture that is presence in every state in the country. The $\mathrm{ABC}$ institution also undertakes many projects which include designing the interior of the mosques. The $\mathrm{ABC}$ foundation receives the support from the Government and 
the State. The building premise of the ABC institution is in fact built on the land donated by the State.

Consistent with the Islamic definition of waqf, the term endowment at $\mathrm{ABC}$ institution also reflects

“..stop. Endowment compared to charity is more societal and widespread as well as continuous, permanent and non-individualistic".

It can be inferred from the above definition that the benefits generated from waqf are far more enriching relative to other forms of charity since it can be utilized also to benefit the society at large and the rewards for the donor extend beyond the present life only due to the perpetuity nature of waqf properties donated. Hence, based on the phenomena of endowment during the height of Islam as the core of economic development, the founder of the foundation established ABC Institution with the purpose to undertake waqf Quran. The Quran Endowment Program is considered as the country's first fully illuminated Quran Mushaf. The General Manager of the Yayasan Waqf explained that

“.. Muslims are invited to contribute towards the development of the ummah

that is forwardlooking, knowledgeable and highly cultured in line with the demands of the Quran through the program of Quranic endowment."

The institution receives the cash donation from individuals, corporate entity and government bodies to produce Quran which is then donated to the public, specific groups/ community in the country or other Muslim countries. Individuals can give cash equivalent to the number of copies of Quran that they wish to donate. The cash collected is then used to produce copies of Quran. Currently, the printing activity is outsourced to several printing companies. However, future waqf of the Quran will be produced at the institution's own printing company upon the completion of the building. The development of the original copy of the Quran before printing of copies of the Quran is carried out at the institution's Research \& Development department. All the writings in the Quran are beautifully crafted by the calligraphers at the institution. At the same time, unique motifs are designed on to the pages of the Quran. Each chapter in the Quran has different motifs which conform to the Shariah principles. Copies of the Quran published by $\mathrm{ABC}$ institution are perceived as unique due to the unique motifs, design and writing style adopted. Thus, according to all the interviewees, many donors are attracted to the Quran Endowment program carried out by $\mathrm{ABC}$ institution.

The setting up of the $\mathrm{ABC}$ institution is consistent with the saying of the Prophet Muhammad (PBUH). As narrated by Abu Hurairah (R.A), the saying of the prophet means

\section{"As deemed that would follow a Mukmin from} his deed and goodness after his passing is his knowledge that he has taught others and that which he has spread: children (of all ages) that are religiously inclined (soleh) that he leaves behind; Mushaf (Al-Quran) that he inherits; mosque that he builds; house that he builds for ibmu sabih (the traveller); or well that he digs to water his fields; charity that is made from funds gathered while he was healthy and alive; all will follow him after his death."

Besides ABC institution's Quranic Endowment program, the institution undertakes Waqf Educational Program. A college was set up, and it is registered under the Ministry of Higher Education Malaysia (MOHE). The college is recognized as the first learning institution in the country to offer programmes of study in the field of Islamic arts using the latest technology and software applications. The Vice President of the college stated that the aspiration to build the college emerged after the Quran Endowment Program initiative. Through this project, knowledge, and skills relating to the Islamic Arts especially mushaf, 
calligraphy and zukhruf art can be explored and expanded. The waqf college programmes have now expanded to include other programmes such as Foundation in Business, and Diplomas in Islamic Banking, Islamic Early Childhood Education, and Automotive Engineering. The philosophy of the college centers on

“.. to spread the knowledge of Islamic Arts based on Tauhid and the true teaching of Islam (Shariah Islam). This institution aims at generating students that are all rounded mentally, physically and spiritually and also able to handle the working world challenges and in particular the art world."

According to the Vice President of the college, the waqf education program refers to the provision of scholarship, accommodation, and transportation to students at the colleges. All the students at the college are awarded accommodation and transportation facilities however the scholarship is awarded to only the deserving student. He said

"Waqf education program is specifically for the students. It is in the form of scholarships, accommodation and transportation........ the scholarship component is under the waqf fund which comes from other projects. The waqf Quran is another component. We cannot disturb that fund contributed by donors. The contribution from donors is deposited into a separate account at the bank meant only for waqf Quran."

Besides producing copies of the Quran for waqf endowment program, the institution also produces the Quran which is then sold to the public. The initiative of focussing on the Quran contributed to the sustainable performance of the ABC institution. The Vice President informs

"The institution is self-sustain because it focuses on the Quran and producing different styles of Quran. We called it conventional style, i.e., the mushaf, coloring, and presentation. So whatever they get so they sell it outside. That is some sought of their income. That is sustainable, but sometimes the institution undertakes interior design (ID) projects. ... This is because the students are being trained to write the Quran, they come out with very good design. So to sustain the ABC institution, the design work outputs such as manuscript are sold to the public."

To surmise, the ABC Institution besides performing Quran Endowment and Educational Endowment Programs also undertakes interior design activities that focus on Islamic elements such as the interior design of mosques and, producing and selling Quran to the public.

The founder of the institution has also established other companies and these organizations have continually contributed to the running of the $\mathrm{ABC}$ institutions as well as the college. The allocation from his profit-making businesses helps to cover the operating expenses such as the salary of staffs, R\&D costs and other overhead costs incurred by the ABC institution as well as the college. Hence, one of the driving factors can be associated with the founder's strategic leadership qualities which enable the attainment of the goals of the institutions and its sustainable performance. The founder sets the direction of the institutions, design the organization and nurture a culture that focuses on acquiring knowledge and possessing Islamic values. The traits such as becoming a role model to his staffs, proactive and a high-risk taker possess by the founder aided in the sustainable performance of its waqf programs and the institutions. The informants pointed that the Islamic values embraced by the founder which included among others extending the wealth created from his portfolio of businesses to the society have contributed to the success of $A B C$ institution as well as his other profit making enterprises. Further to that, the founder ensures that the appropriate internal control mechanism is set at up at the organization. 


\section{Key Factors Driving Performance}

An Islamic scholar from a public institution of higher learning stated that there is a need for everybody especially the authorities responsible for managing waqf assets to have an open and healthy mindset coupled with possessing the Islamic spiritual values. With such mindset, they would be able to appreciate better the purpose of corporate waqf, which is to generate more income to elevate the status of the society including non-Muslim. The Islamic Scholar said

\section{"We need to look at waqf and beyond it as well as from the perspective of an economic agenda that can generate more income for Muslim specifically and others too."}

The embracement of Islamic spiritual values among the employees facilitates the achievement of the goals of the ABC institution. When employees possess the right spiritual values, their intention in anything that they do will be sincere which subsequently ease their daily tasks. The Advisor to the institution stated that

$$
\begin{aligned}
& \text { “..it is very challenging to manage waqf } \\
& \text { properties, but with strong spiritual values } \\
& \text { presence among the employees, all waqf } \\
& \text { programs were successfully carried out." }
\end{aligned}
$$

The informants concur with the view about the primary purpose of managing waqf in a contemporary manner via corporate waqf landscape, however, to better understand and appreciate the purpose of corporate waqf and in mobilizing the resources it is pertinent to tackle the fundamentals of waqf. As put forth by one of the informants

"First of all, define everything in the context of Islamic principles, Islamic values, and the Shariah. The fundamentals also include the halal and haram. Then the effect is easier to tackle. But the mindset issue and the motivational issue and that is the reason why we use jihad. Once you used jihad, all the principles ought to be related to jihad. So, you have to define it so that all will be in line."

Jihad in this context refers to an exerted effort to allow Islam to transform traditional waqf process into a business that can generate continuous income for the ummah besides ensuring that the waqf assets perpetuity is sustained. There is a need also for the individuals involved especially at the management level in the waqf institutions to remain motived and taking it as a national agenda besides possessing sufficient knowledge of waqf fundamentals and doing it the jihad way.

The Vice President of the Waqf College and the GM of the $\mathrm{ABC}$ institution pointed out that it is pertinent to develop all waqf properties to generate more and continuous income so that wealth can be shared by the ummah. The President highlighted that for example there are many idle lands in Negeri Sembilan and only if these land are donated to become waqf assets, much more benefit can be generated to enhance the socio-economic of the society. He said this scenario could be attributed to the lack of understanding of the waqf fundamentals among Muslim. At the ABC institution, every employee regardless of their position is required to reach out to the public to participate in waqf Quran Mushaf. The ABC institution regularly collaborated with government and corporate bodies to conduct waqf Quran, and some of the programs carried out are organized at national level.

The $\mathrm{ABC}$ institution does advertise to encourage Muslim to partake in Quran Mushaf. They humbly believe that marketing is an excellent way to reach greater audience. However, this was not carried out much due to the high cost involved. Nevertheless, they agree that the individuals involved in managing and administering waqf funds and assets must be trustworthy, committed, accountability besides possessing jihad attitude and in-depth Islamic fundamentals and waqf concepts. Similarly, the Islamic scholar explained that mutawalli criteria must be stipulated and each of them 
must possess the right attributes. They too must be continuously monitored and evaluated. Only then, the resources encompassing waqf assets and funds and the human resource can be better mobilized so that both donors and beneficiaries can benefit not just in the short term but in the long run too.

It is also crucial to monitor and evaluate the performance of $\mathrm{ABC}$ institution and the beneficiaries. Without any proper performance measurement system in place, monitoring and controlling of operations and resources cannot be carried out. Such absence could lead to many issues faced such as mismanagement, corruption, dishonest mutawalli, underdeveloped and negligent of waqf properties and poor public confidence.

As in the case of the institution, standard operating procedures (SOP) have been developed to ensure the smooth running of their operations and to implement all their activities effectively. All the employees must comply with the rules and regulations of the institutions besides embracing the Islamic values. They must be trustworthy and sincere in carrying out their roles at the institutions and as a khalifah in this world. Thus, the employees also are required to meet their key performance indicators (KPI). For example, all employees as previously stated are required to participate in Quran Mushaf. Thus, each of them is given their respective target according to their job categories. Hence, to achieve this KPI, they are required to seek individuals to participate in the Quran Mushaf.

At the beneficiaries' level, these institutions also have measures to evaluate the beneficiaries in terms of performance and attributes. Firstly, the beneficiaries must meet the specific attributes regarding their eligibility to qualify as the recipient of the scholarship to study at the college. Their performance will be evaluated based on education performance besides spiritual values. The evaluation goes beyond graduating from the college. The college also determines beneficiaries' success concerning gaining employability as well as the ability to improve their status in the society.

The results of the study showed that performance measurement for waqf institutions cover beyond the financial measures to achieve a holistic perspective. It is also essential for individuals involved to possess an in-depth understanding of waqf fundamentals, change the mindset, address motivational issues and ensure transparency and accountability within the institutions.

The results revealed that the case company successfully engaged in waqf practice as well as, sustain its performance. The essential criteria in efficiently managing and administering waqf funds at the case company can be linked to the jihad attitude, healthy mindset, an in-depth knowledge of Islamic and waqf fundamentals, possess right spiritual values, is highly motivated and strategic leadership. The findings put forth to contribute to advance the literature on corporate waqf, besides provide insights for policymakers on the drivers for an effective and efficient management of waqf funds and sustainable corporate waqf performance.

(i). How is the performance of the selected corporate waqf case institution?

(ii). What key factors enable the effective management of waqf properties within the selected corporate waqf case institution?

\section{Conclusion}

This article examines the sustainable performance of a selected waqf institution in Malaysia as well as, the key factors that facilitateits management of waqf properties. The results revealed that the case company successfully engaged in waqf practice and it was able to sustain its performance in the long run. The essential criteria in efficiently managing and administering waqf funds at the case company can be linked to the jihad attitude, healthy mindset, an in-depth knowledge of Islamic and waqf fundamentals and strategic leadership. 
Overall, the main findings reveals that the new and modern waqf management via corporate waqf has put more significant emphasis on the principles of accountability and transparency to ensure the continuity and development of waqf assets so that wealth can be distributed to the ummah effectively. It is essential for the management and the human resource entrusted to manage waqf properties to also look beyond the traditional way of mobilizing resources, managing and administering the waqf assets. It is also crucial to ensure internal control system is in place at the institution to ensure smooth operation of waqf programs and the institution goals are achieved. Also, the measurement used should incorporate both financial and non-financial measures to evaluate the waqf institution and the beneficiaries. The adoption of an appropriate internal control mechanism can lead to enhance the performance of the institution and ensure the management and the administration of waqf assets are effective. With a more organized, systematic and effective management of waqf assets, coupled with the right performance measures, waqf institution will be better able to reach out to the society and elevate the beneficiaries status. Additionally, with active professional participation in its management, waqf institutions can ensure its vibrant nature and active role can be sustained over time. The findings from the study contribute to advance the literature on waqf specifically about the crucial factors that drive sustainable performance of waqf institutions. The present results also offer some insights on how best to overcome the recurring issues faced by many waqf institutions.

\section{Acknowledgements}

The authors wish to express their gratitude to Accounting Research Institute, Universiti Teknologi MARA for funding this research project. The authors also acknowledged the Faculty of Accountancy, Universiti Teknologi MARA for facilitating the research project.

\section{References}

Arshad, R. and Mohd Zain, N. (2017). Performance measurement and accountability of waqf institutions in Malaysia. SHS Web of Conference. 36, 00005, pp. 1-15. Retrieved from https://www.shs-conferences.org/articles/ shsconf/.../2017/04/shsconf_icga2017_00005.

Auditor General's Report. (2014). Auditor General's Report (2014). The Activities of the departments/agencies and management of State Government's companies,3rd Series. Retrieved from https://www.audit.gov.my/index.../518negeri-2014-siri-3-pub

Aziz, N.F. and Said, I. (2011). The Trends and Influential Factors of Children's Use of OutdoorEnvironments: A Review. Asian Journal of Environment-Behaviours Studies. 2 (5) 67 79 .

Bryman, A. and Bell, E. (2011). Business Research Methods (3 ed.). New York: Oxford University Press Inc.

Creswell, J.W. (2012). Educational Research: Planning, Conducting, and Evaluating Quantitative and Qualitative Research (4 ed.). Boston: Pearson Education Inc.

Darus, F., Shukri, A.H. A., Yusoff, H., Ramli, A., Mohammad Zain, M. and Bakar, N.A. A.

(2017). Empowering social responsibility of Islamic organizations through Waqf. Research in International Business and Finance. 42 pp 959-965.

Gugui, P.C. and Rodriguez-Campos, L. (2007). Semi-structured interview protocol for constructing logic models. Evaluation and program planning, 30, 339-350. 
Hassan, A. and Shahid, M.A. (2010). Management and development of the waqf assets. Paper presented at the Seventh International Conference -The Tawhidic Espistemology: zakat and waqf economy. Bangi, Malaysia.

Ibrahim, D. and Ibrahim, H. Revitalising of Islamic Trust in institutions through Corporate Waqf. Proceeding of the 4th International Conference on Business and Economic Research. 192-202.

Jamshed, S. (2014). Qualitative research method-interviewing and observation. Journal of Basic and Clinical Pharmacy, 5 (4), 87-88.

Johari, N., Mustaffha, N. and Hameed, L.B.M. (2016). Internal control issues in waqf management : insights from the literature. Proceeding of the 3rd International Conference on Management \& Muamalah.

Kahf, M. (1998). Financing the development of awaqf property. Seminar of development of awaqf, Kuala Lumpur, Malaysia.

Kahf, M.(2003). The role of Waqf in improving the Ummah welfare. In: Paper presented to the international seminar on Waqf as Private Legal Body organized by the Islamic University of North Sumatra, Medan, Indonesia. January 6-7.

Noordin, N. H., Haron, S. N. and Kassim, S. (2017). Developing a comprehensive performance measurement system for waqf institutions. International Journal of Social Economics. 44(7) pp.921-936.

Ministry of Finance (2011). Pembangunan Waqf Corporate: Mentransformi Ekonomi Ummah. Retrieved from www.igra.org.my/ index.php?option $=$ com_content\&view $=$ articl e\&id=111\&itemid=209.
Muslim, M.H., Karim H.A. and Abdullah, I.C. (2013). Well-Being of UiTM Shah Alam Students Living in Off-Campus Environment. Asia Journal of Environment-Behaviours Studies. 4(13), 147-158.

Nadwi, A.M. (2015). A framework for corporate governance for waqf: a preliminary proposal. Retrieved from https://www.researchgate. net/.../283420175_A_New_Framework_of_ Corporate_Govern

Patton, M. Q. (2002). Qualitative research and evaluation methods. (3 ed.): Sage Publications.

Osman, A. Z. (2010). Accountability of waqf management: Insight from praxis of nongovernmental organization (ngo). Seventh International Conference- The Tawhidi Epistemology: Zakat and Waqf Economy Proceeding.

Rahman, A. A. (2009). Peranan Waqf dalam Pembangunan Ekonomi Umat Islam dan Aplikasinya di Malaysia. Syariah Journal. 17 (1),113-152.

Ramli, A. M. and Jalil, A. (2013). Banking Model of Corporate Waqf: An Analysis of Waqf Selangor Muamalat. Retrieved fromhttps:// comaif.files.wordpress.com/

Ritchie, J., and Lewis, J. (Es.). (2003). Qualitative Research Practice: A guide for social science students and researchers. London: Sage Publications Ltd.

Saad, N. M., Kassim, S and Hamid, Z. (2013). Involvement of Corporate Entities in Waqf

Management: Experiences of Malaysia and Singapore. Asian Economic and Financial Review. 3 (6), pp 736-748. 
Strauss, C. J. (2008). (3 ed.). Basics of Qualitative Research: Techniques and Procedures for Developing Grounded Theory. Thousands Oaks, California: Sage Publications.

Sualaiman, M., Adnan, M. A. and Nor, P. N. (2009), Trust me! A case study on the international Islamic University waqf fund. International Association for Islamic Economics, review of Islamic Economics. 13 (1) pp. 69-88.

Toraman C., Tuncsiper B. and Yilmaz S. (2007). Cash Awaqf in the Ottomans as philatropic foundations and their accounting practices. Proceeding of the 5th Accounting History International Conference, Banff, Canada pp. 9-11.

Yin, R.K. (2009). Case Study Research: Design and Methods (4 ed.). Thousands Oaks, SAGE Publications.

Zahrah, M.A. (2007). Pengantar Sejarah Waqf. Waqf: Menurut Agama dan Undang Undang. Selangor, Malaysia: Berlian Publications Sendirian Berhad. 